\title{
Lending and Cash Required Reserve: Empirical Evidence from Ethiopian Commercial Bank
}

\author{
Mitku Malede Yimer \\ Lecturer at University of Jigjiga \\ Department of Banking and Insurance, Ethiopia
}

Doi: 10.19044/esj.2018.v14n13p179 URL:http://dx.doi.org/10.19044/esj.2018.v14n13p179

\begin{abstract}
The study was mainly intended to determine the effect of cash required reserve on commercial bank lending in Ethiopia using panel data of eight purposively chosen commercial banks over the period of eleven years (2005 to 2015). The investigation tested the relationship between commercial bank lending and cash required reserve. Eleven years financial data of eight purposively chosen commercial banks were used for analysis purpose. Ordinary least square model was applied to test the impact of predictor variable on commercial bank lending. The result suggests that, there is no significant relationship between commercial bank lending and cash required reserve in Ethiopian commercial. This study suggests that commercial bank have to give less emphasis to cash required reserve because it doesn't weakens banks credit creation ability and does not leads a bank to be insolvent.
\end{abstract}

Keywords: Lending, cash required reserve and commercial banking

\section{Background of the Study}

Lending is the activity of granting loan and advance and it is the main function of commercial banks in view of its significant contribution to the financial health of banks through interest income earnings. Therefore Bank loan is typically the largest asset and the predominant source of income for banks. Since 1963 commercial banks in Ethiopia function well by accepting all types of deposit, there after it grant loan and advance to borrowers for the sake of increasing their investment capacity. In this function commercial bank plays a great role for the growth of the economy by maintaining its liquidity. Hence, cash required reserve become marginal way to maintain banks liquidity. Successively, national bank of Ethiopia under article 2.1(A) directives set this requirement. These policies or requirements are now at the center of worldwide contention -some researchers believe such requirements promote disintermediation of commercial bank credit while others stand at the 
opposite. Christian G. \& Pascal t. (2012) believe that, an increase in reserve requirement leads to a contraction in domestic credit. If deposits that are subject to reserve requirements are not perfectly substitutable with other sources of funding, higher reserve requirements increase marginal costs for banks. Consequently, the lending-deposit rate spread raise at the same time total credit fall. Cargill and Mayer (2006) also contended that, an increase in reserve requirement case to decrease bank credit. Moreover, Montoro and Moreno (2011) found that, a raise in reserve requirements makes large the spread between deposit and lending rates. This in turn makes less attractive for foreign investors to lend to domestic banks. Consequently, it makes more expensive for domestic borrowers. In short a raise in reserve requirement may achieve a contraction in domestic credit. On the other hand Friedman and Schwartz (1963) claim that, a raise in Commercial bank cash required reserves sources to increase its credit creation ability. Olusanya, s. et al, (2012) also reveal that, required reserve has positive impact on commercial bank loans and advances. I.e. banks credit raise when cash required reserve increase. Again, Meltzer (2003) reveals that a raise in reserve requirements would have little or no impact on credit supply. Chandler (1971) also supports by uttering that an increment in reserve requirements does not encourage banks to hold back their lending or sell securities or cause interest rates to rise. Further, Wilcox (2012) sustains that changes in reserve requirements had only small and statistically insignificant impacts on bank loans and investments. These various approaches have been used to examine the effects of cash reserve on a far-reaching array of banks credit alhough, the evidence is not uniform and consistent in indicating whether cash reserve affects commercial banks' credits or not. Generally, this study was aimed to confirm the effect of cash required reserve on commercial banks' lending and thereby, to provide empirical evidence on the effects of cash required reserve changes on commercial bank credit.

\section{Statement of the Problem}

Lending is the main function of commercial bank that generates income for banks than other service. Banks accept deposits and use that fund to grant loans to borrowers or invest in other assets that will yield a return higher than the amount bank pays the depositor (McCarthy et al., 2010). Therefore it is comprehensible that, the main source of lending is deposit; but the amount that would have to be lent is the excess reserve and the remaining percentage of deposit kept as a reserve for the purpose of maintaining its liquidity. Still, loan is the most profitable and liquid asset for the bank to maintain its maximum liquidity obligation; bank do not invest its entire fund in a profitable asset (Nwankwo, 1980). 
In Ethiopia, under Article 2.1(A) of the directive, National Bank of Ethiopia requires every bank operating in the country to maintain a reserve amounted as five percent of all birr and foreign currency deposit held in the form of demand, saving and time deposit. Accordingly; even bank's loan is the main means of income for the bank, commercial banks in our country didn't invest the entire amount of deposit accepted in this profitable asset rather they keep idle a portion of its resources to meet cash required reserve. Though, this requirement is aimed at maintaining bank liquidity it sweep question whether a cash reserve requirement shrinkage domestic credit or not. As far as the researcher concerned, there is no a researcher who tried to deal with the effect of cash required reserve on commercial banks' lending in Ethiopia.

\section{Purpose Statement}

The main objective of this study was to investigate the effect of cash required reserve on Ethiopian commercial banks' lending. More specifically, this study was aimed at addressing the following specific objective;

$\checkmark \quad$ To determine the effect of cash required reserve on commercial banks' lending.

\section{Statement of Hypothesis}

To achieve the study's objective the researcher fashioned the main arguments of the study in to one research hypothesis.

$\checkmark \quad$ H1: There is relationship between commercial banks' lending and cash required reserve.

\section{Significance of the Study}

Commercial bank plays a great role for one countries economic growth, which is realized by forming capital for individuals and business. Conducting this investigation is expected to result in some importance for practitioners and policy makers besides to its academic importance. The study also expected to have policy making relevance for bank management. Being aware what factors would influence bank lending enables a bank management to formulate a policy in the way that permits to improve banks' lending function. Moreover, it will serve as an input for further study by providing empirical evidence about the effect of cash required reserve on commercial bank lending.

\section{Scope and Limitation of the Study}

The study was conducted on the effect of cash required reserve on commercial banks' lending in Ethiopia case from 2005 up to 2015. Banks which was considered for this study was Commercial Bank of Ethiopia (CBE), Construction and Business Bank (CBB), Dashen Bank (DB), Awash Bank 
(AB), Wegagen Bank (WB), United Bank (UB), NIB Bank (NB) and Bank of Abyssinia (BA) and eleven years financial data were collected from these banks.

\section{Literature Review \\ Lending}

Lending is the dependent variable for this study which implies that a Provision of fund by a bank to borrowers. This variables measured by natural logarithzem of net loans and advances granted by commercial bank as used by (Karumba, Wafula, 2012)

\section{Cash Required Reserve}

This regulation requires each commercial bank to maintain minimum cash reserves to customer's deposits and notes. All commercial banks hold some percentage of deposits at the national bank. I.e. the Federal funds are reserves held in a bank's account with its Federal Reserve Bank (McGrawHill, 1951). The underlying principle of this requirement is to maintain bank from its liquidity. I.e. when losses occur on a bank's loans the amount lost is first covered from profits then from regulatory capital. If these are not sufficient, bank failure and loss of bank deposits can occur. Reserve requirement ratios vary across different types of deposits. Reserve requirement measured as weighted average of all reserve requirements and Effective Reserve Requirements Robitaille (2011), Banco (2011) and Terrier et al. (2011). Small banks are partly exempted from reserve requirement regulation. An exemption entry exists on a variety of deposits above which compulsory reserve requirements apply. If a bank's deposit volume is below the exemption value the reserve requirement regulation becomes obsolete. Banks required amount of reserves equals to the required reserve ratio times the total deposits in the bank (Case and Fair, 2007).

The precise determination or which bank liabilities to include in reserve base has more significant implication for monetary control and resources allocation than for bank liquidity rather the reserve requirement based on the bank asset has tended to affect more on the allocation of credit (Coasts, 1980).

Required reserve is a measure of required reserves/assets which is a ratio of legally required reserves relative to total assets. Required reserve equals to legal required reserve/total asset (Charles et al, 2011).

\section{Gap in Literature (Need of the Study)}

The effect of cash required reserve on commercial bank lending had been investigated a lot. However, the issue investigated, it lacks common unanimity among the researches. Henceforth, the issue songs for further study. 
Accordingly, the researcher comes in a position to investigate this impression in Ethiopian case using elven year's panel data from eight commercial banks from 2005 up to 2015.

\section{Research Methods and Methodology}

This section presents the methods that were employed to achieve study's objective. It entails research design adopted to examine the effect of cash required reserve on commercial banks' lending, type and sources of data, population, sampling design and sample size, the process of constructing empirical model with identification and measurement of its components, finally it reveal method of data analyzing instruments.

\section{Research Design}

The main objective of this study was to investigate the effect of cash required reserve on commercial banks' lending. To achieve the objectives of the study Ordinary least square model for 11 year cross sectional panel data was used. Panel data analysis is a method of studying a particular subject within multiple sites, periodically observed over a defined time frame. This method assumes that individuals, firms, states or countries are heterogeneous. And also it offer a benefit which cannot be obtained from other methods because it provides more informative data, less collinearity among variables, more efficiency, and more degree of freedom and minimizes bias (Gujrati, 2004). With repeated observations of enough cross-sections, panel data analysis enables the researcher to investigate the dynamics of change within a short time series. The amalgamation of time series with cross-sections can boost the quality and quantity of data that would have been unattainable using only one of these two dimensions (Yaffee, 2003). Balanced panel type was used for this investigation because data were collected equally from all sampled banks throughout observations.

\section{Type and Sources of Data}

To examine the relationship between cash required reserve and bank lending the study used secondary data due to availability and its quality. Secondary data include the higher quality data compared with primary data (Stewart and Kamins, 1993). Secondary data are easily accessible, relatively inexpensive, and quickly obtained (Malhotra, 1996). Secondary data was sourced from financial statements of sampled banks. then and there, panels of eleven years financial data of sampled banks were obtained from national bank of Ethiopia which covers from 2005-2015. 


\section{Population, Sampling Design and Sample Size}

Population is a group of items that a sample will be drawn from (Diamantopoulos, 2006). In our country 19 Commercial Banks are in operation. Out of these commercial banks, eight banks were taken for the purpose of this investigation, which have prepared annual report of 2005/06 onwards. Accordingly AIB, BOA, CBB, CBE, DB, NIB, UB and WB were selected purposively for this investigation due to the availability of data for the study period.

In conducting researches, it is often costly to collect data from all potential units of analysis or population. Therefore, a smaller number of units or sample is often chosen to represent the whole population. Hence, for this study Purposive sampling technique was used by taking in to account the availability of data, cost and time. Purposive sampling is a type of sampling in which a particular event is deliberately selected for the importance of information that cannot be gotten as well from other choice (Maxwell, 2003). Data were collected from sampled banks spanning from 2005 up to 2015. The cut off year was by considering that it offers recent time series observations. In line with this, eight banks fall in the sample frame. Thereafter, eleven years data were extracted from those banks to be used for regression purpose.

\section{Method of Data Analysis}

Data collected to achieve objective was analyzed and interpreted using multiple regression analysis, descriptive statistics and Pearson correlation matrix with a package of version 11 stata software. While descriptive statistics measures the mean and standard deviation of the variable; Pearson correlation analysis used to measure the correlation between variables. To check whether regression assumptions are violated OLS assumption checks were carried out. I.e. Multicollinearity test by variance inflation factor and Pearson correlation matrix, normality of data by Shapiro wilk test, Hetroskedasticity test by BreshPagan/Cook-West and information matrix test, and Ramsay RESET (regression specification error test) test was also used for model specification test.

\section{Model Specification}

Ordinary least square model was used to test hypothesis. Hence, the study model has been developed as follows;

$\mathrm{Ld}=\mathrm{f}(\mathrm{rr})$.

Thus, the regression equation for this study becomes;

Ld i, $\mathrm{t}=\alpha 0+\beta 7$ Rrit $+\mu$

Where: ld: lending

rr it: Cash required reserve of bank $i$ at time $t$. 


\section{Results and Discussion}

To contribute to the existing knowledge on the effect of cash required reserve on commercial banks lending, the researcher investigated the relationship between Ethiopian commercial banks' lending and cash required reserve. The researcher to analyze the finding of the study used descriptive statistics and multiple regression analysis which enables to test whether independent variables influence the dependent variable including the sign of its effect.

\section{Descriptive Statistics}

Table 4.1 presented below shows the descriptive statistics of dependent and independent variables which explains the average value of each variable, how far (deviate) each variable from its mean and the minimum \& maximum value for each variables. This is generated to give overall description about data used for analysis and served as data screening tool to spot unreasonable figure. As shown in the descriptive statistics table below, on average the loans and advance granted by each sampled commercial banks was 2403 billion birr in each year for the test period and the minimum and maximum loans was 2756 and 4307 billion birr respectively and it deviate from its mean value by 3211 billion birr. Sampled banks mean value of cash reserve for the study period was 2.25 percent. It indicates that, on average each sampled bank maintain 2.25 percent of its total asset at national bank of Ethiopia to meet cash reserve requirement as well as to maintain its liquidity. The minimum and maximum amounts each sampled bank kept at national bank as a legal reserve was $0.39 \& 4.75$ percent of asset for the study period. This reserve amount deviates from its average value by 0.0073992 percent

To sum up as descriptive statistics table shows, Cash required reserve have low standard deviation. Which indicates that, sampled commercial bank cash required reserve was remain stable for the study period of each bank.

Table 4.1 descriptive statistics

$\begin{array}{llllcr}\text { Variable } & \text { Obs } & \text { Mean } & \text { Std. Dev. } & \text { Min } & \text { Max } \\ \text { ld } & 88 & 3.38191 & .32111 & 2.756 & 4.307 \\ \text { rr } & 88 & .0225 & .007399 & .0039 & .047\end{array}$

\section{Regression Results}

For this investigation to determine the effect of cash required reserve on Ethiopian commercial bank lending, eight banks financial data from 2005 up to 2015 was used. Hence, hypothesis testing become mandatory than of descriptive statistic. So that hypotheses were tested at $1 \%, 5 \%$ and $10 \%$ level of significance a two-tailed test. 


\section{Key results}

As displayed in the regression result table below, R-square of the model was about $20.02 \%$, which implies, 20.02 percent of change in commercial banks' lending explained by cash required reserve. $\mathrm{P}$-value of $\mathrm{F}$ stastics (Prob $>\mathrm{F}=0.00000)$ is significant at 1 percent level of significance. Hence, it reveals that a model used for this study was also good enough fitted.

\begin{tabular}{lcccc} 
& & Table 4.3 Linear regression result; \\
rr & Coefficient. & Std. Err. & T-statistics & P-value \\
Cons $\quad .0134959$ & .0295741 & 0.46 & 0.650 \\
Number of obs $=88$ & .0047986 & -6.64 & 0.000 \\
$\mathrm{~F}(8, \quad 47)=53.02$ & & R-squared $=0.2002$ & \\
Prob $>\mathrm{F}=0.0000$ & \multicolumn{3}{c}{ Adj R-squared $=0.1833$} \\
\end{tabular}

The analysis suggests that, cash required reserve have positive statistically insignificant relationship with commercial bank lending. For that the null hypothesis, which states there is no relationship between cash required reserve and commercial bank lending was accepted and the alternative hypothesis was rejected. Hence, Ethiopian commercial bank lending didn't influenced by cash required reserve from 2005 to 2015. This finding agrees with; Wilcox, James A. (1984), Meltzer (2003) and Chandler (1971). Refutes by Christian G. \& Pascal t. (2012) findings that show, a significant relationship between reserve requirements and commercial bank credit.

\section{Summery, Conclusion, Recommendation and Suggestion for Further Research}

This chapter presents a major summary of the findings, conclusions, recommendations for practitioners and areas for further research.

\section{Summery}

This study examined the relationship between Ethiopian commercial banks' lending with cash required reserve Using Lending (LD) as dependent variables. These parameters were estimated using the Ordinary Least Square (OLS) method. The study reveals that cash required reserve have no significant impact on commercial bank lending.

\section{Conclusion and Recommendation}

According to study findings, Cash required reserve affects commercial bank lending positively however it is insignificant.

Commercial bank is the leading financial institution in granting of loans advances to individuals, business or firms. Once more this service is the main means of revenue for the bank. Accordingly, to improve commercial bank lending central bank should decrease cash required reserve as much as possible. 


\section{Suggestion for Further Research}

This investigation fails to consider volume of deposit, bank size and interest rate that may affect commercial bank loan and it focus only the effect of cash required reserve on commercial banks' lending. So if someone investigates this issue by incorporating the above stated determinant using both secondary and primary data the finding may be relatively fruit full.

\section{References:}

1. Abd Karim, M., Mohd Harif A., \& Adziz A. (2007). Monetary Policy and Sectoral Bank Lending in Malaysia. Global Economic Review, 35(3), 303-326.

2. Adedoyin \& Sobodun (1996). Commercial Banks Lending Activities in Nigeria. Nigerian Financial Review, 9(3), pp. 36-37.

3. Alejandro, Micco and Ugo Panizza (2004). Bank Ownership and Lending Behavior: Inter- American Development Bank. Working Paper. No-520 November pp 1-19

4. Andrew Fight (2004). Credit risk management: essential capital markets. Elsevier Butterworth heinemann press.

5. Belai, G. (1987). Currency and banking: Ethiopia.

6. Bikker, J. A. \& H. Hu. (2002). Cyclical patterns in profits, provisioning and lending of banks and procyclicality of the new Basel capital requirements. BNL Quarterly Review, 55:14375.

7. Carletti., Cerasi V. \& Daltung, S. (2006). Multiple-Bank Lending: Diversification and Freeriding in Monitoring. Working Paper.

8. Charles, W. Calomiris Joseph, R. Mason and David C. Wheelock (2011). Did Doubling Reserve Requirements Cause the Recession of 1937-1938? A Microeconomic Approach: Working Paper.

9. Chernykh, L. \& Theodossiou, A. (2011). Determinants of Bank LongTerm Lending Behavior: Evidence from Russia. Multinational Finance Journal, 15(1): 193-216.

10. Chodechai , S. (2004). Determinants of Bank Lending in Thailand: An Empirical Examination for the years 1992 - 1996. Unpublished.

11. Coast, warren w. L. (1980). The use of reserve requirement in developing countries. Money and monetary policy in less developed countries: a survey of issues and evidence.

12. Coyle, B. (2000). Framework for Credit Risk Management: Chartered Institute of Bankers, United Kingdom.

13. Creswell, J.W. (2009). Research design: Qualitative, Quantitative and Mixed Method approach (3rd ed.). U.S: SAGE publication Inc.

14. Eustacius, N. and David, J. L. (1995). Factors Affecting Commercial Bank Lending to Agriculture. 
15. Ewert, R. \& Schenk, G. (1998). Determinants of Bank Lending Performance. Working Paper,Center for Financial Studies. University of Frankfurt.

16. Ewert, R., Szczesmy A. \& Schenk, G. (2000). Determinants of Bank Lending Performance in Germany. Business Review, 52, 344 - 36.

17. Frost, Peter A. (1971). Banks Demand for Excess Reserves. Journal of Political Economy 79, July, pp. 805-25.

18. Glocker, C. and P. Towbin (2012). Reserve Requirements for Price and Financial Stability: When are they effective? Forthcoming in International Journal of Central Banking.

19. Goldenweiser , E. A. (1951). American Monetary Policy: New York. McGraw-Hill.

20. Goldfeld \& Chandler (1980). Lending behavior of Commercial bank (2nded.): Macmillan Publication.

21. Gujarati, D. (2004). Basic Econometrics (4ed): McGraw Hill.

22. Hair, J., F., Black, W C., Babin B J., Anderson R. and Tatham L. (2006). Multivariate Data Analysis (6th ed.): New Jersey: Pearson Education.

23. Hamza, A. (1988). Monetary institutions and policy in Ethiopia: outline of historical inclusion. Addis Ababa University: Unpublished.

24. Hanes, C. (2006). The Liquidity Trap and U.S. Interest Rates in the 1930s. Journal of Money, Credit, and Banking 38 (1),165-94

25. Hempel, G. and Simonson, D. (1999). Bank Management: John Wiley and Sons. 66-68.

26. Ibrahim, M. (2006). Stock Prices and Bank Loan Dynamics in a Developing Country: The Case of Malaysia. Journal of Applied Economics, 9(1), 71-89.

27. Irina, B. (2003). Bank liquidity and exchange rate regimes: new European Perspectives. $3^{\text {rd }}$ International Scientific Conference, Bulgaria.

28. Karumba, M. Wafula. M. (2012). Collateral Lending: Are there Alternatives for the Kenyan Banking Industry? Working Paper Series.

29. King, R. Stephen (1986).Monetary Transmission: Through Bank Loans or Liabilities. Journal of Money Credit and Banking, Vol. 18, No. 3, pp. 290-303,

30. Malhotra, N.K. (1996), Marketing Research: An Applied Orientation (2nded.). Prentice Hall.

31. Malhotra, N. (2007).Marketing Research: An Applied Orientation (5thed.). PHI, New Delhi.

32. Mary, K., Martin, W. (2012). Collateral Lending: Are there Alternatives for the Kenyan Banking Industry? Working paper. 
33. Meltzer, Allan H. (2003). A History of the Federal Reserve, Volume 1: 1913-1951. Chicago:University of Chicago Press.

34. National Bank of Ethiopia (2008). Ethiopian banking business proclamation No.52/2008. at www.nbe,gov.et.

35. National bank of Ethiopia (2008). Asset classification and Provisioning Directive No.SBB /43/2008. National Bank of Ethiopia, Addis Ababa Ethiopia.

36. National bank of Ethiopia, (1994). Monetary and Banking Proclamation No.83/1994. Available at www.nbe.gov.et

37. Olokoyo, f. (2011). Determinant of commercial bank's lending behavior in Nigeria. International Journal of Financial Research, 2(2), 61-72.

38. Oloyede, B. (1999). Principles of Money and Banking (4thed.). Ado: Educational Publishers. 